\title{
Drivers to sustainable manufacturing practices and circular economy: a perspective of leather industries in Bangladesh
}

\author{
Md. Abdul Moktadir, Towfique Rahman, Md. Hafizur Rahman, Syed Mithun Ali \\ Department of Industrial and Production Engineering \\ Bangladesh University of Engineering and Technology \\ Dhaka-1000, Bangladesh
}

\author{
Sanjoy Kumar Paul \\ UTS Business School, University of Technology Sydney, Australia \\ Corresponding email: sanjoy.paul@uts.edu.au (S.K. Paul)
}

\begin{abstract}
Sustainable manufacturing practices and the circular economy have recently received significant attention in academia and within industries to improve supply chain practices. Manufacturing industries have started adopting sustainable manufacturing practices and a circular economy in their supply chain to mitigate environmental concerns, as sustainable manufacturing practices and a circular economy result in the reduction of waste generation and energy and material usage. The leather industry, in spite of it contributing remarkably to a country's economic growth and stability, does not bear a good image because of its role in polluting the environment. Therefore, the leather industries of Bangladesh are trying to implement sustainable manufacturing practices as a part of undertaking green supply chain initiatives to remedy their image with the buyer and to comply with government rules and regulations. The main contribution of this study is to assess, prioritize and rank the drivers of sustainable manufacturing practices in the leather industries of Bangladesh. We have used graph theory and a matrix approach to examine the drivers. The results show that knowledge of the circular economy is paramount to implementing sustainable manufacturing practices in the leather industry of Bangladesh. This study will assist managers of leather companies to formulate strategies for the optimum utilization of available resources, as well as for the reduction of waste in the context of the circular economy.
\end{abstract}

Keywords: Sustainable manufacturing practices; circular economy; sustainability driver; leather industry; graph theory; matrix approach.

\section{Introduction}

The awareness that business is growing with the ongoing and rapid worldwide industrialization indicates the importance of implementing sustainable manufacturing practices and a circular economy. Sustainability is defined by the World Commission on Environmental and Development as "development that meets the needs of the present 
generation without compromising the ability of future generations to meet their needs" (World Commission on Environment and Development, 1987, p. 20). There is a relation between an industry and the environment that is a crucial part of the industrial business performance. According to various criteria, the importance of economic, social and environmental dimensions varies from time to time (Andrews, 2015). It is obvious that the success of an industry largely depends on its manufacturing performance. Accordingly, sustainable manufacturing practices have recently gained popularity due to increased consideration for environmental, social, and economic issues. Sustainable manufacturing is a part of sustainable development, a framework which attempts to maintain a dynamic balance between human, financial and environmental concerns (Lorek and Spangenberg, 2014). In a circular economy, instead of discarding assets after only one product cycle, these are continually re-acquired and reintroduced to market. A circular economy inspires waste reduction. Therefore, this is also a part of sustainable development.

In the leather industry, the term sustainable manufacturing practice does not refer to the indefinite production of leather products, footwear and finished leather. Instead, it denotes the sustainability of human existence by continuously balancing social, environmental and economic conditions (Hu et al., 2011). For a developing country like Bangladesh, the leather processing industry plays a significant role in economic development. Sustainable manufacturing practices will henceforth be the driving force of development in this sector. Sustainable manufacturing practices are gaining popularity in Bangladesh for several reasons (Jayal et al., 2010), including pressure from the market, customer awareness, government promotions and regulations, understanding economic benefits, lowering manufacturing costs, improving quality, attracting direct foreign investment, and knowledge of the circular economy (Lieder and Rashid, 2016). Customer feedback is the main source of pressure from the market (Westkämper, 2008). The government makes rules and regulations and places importance on the green supply chain, remanufacturing and reverse logistics, which are all part of sustainable manufacturing processes. Adopting sustainable manufacturing practices will result in a decrease in costs and improve quality, which will increase direct foreign investment (Roberts and Ball, 2014). Thus, adopting sustainable manufacturing practices in this sector will be beneficial for the development of the country (Baldwin et al., 2005). As the whole world is moving from a linear economy (i.e. extraction of resource to landfill) to a circular economy (recycling with minimal extraction), the leather industry of Bangladesh should also follow this modern trend to achieve the overall sustainable development of the country (Guo et al., 2010).

In the Bangladeshi leather industry, adopting sustainable manufacturing practices and a circular economy is a rising issue. Most previous sustainability studies have been made based on developed countries (Syed et al., 2012). In the context of the leather industry of Bangladesh, little research on sustainable manufacturing practices has been reported (Paul et al., 2013). Leather processing and leather products' manufacturing industries play an important role in the economic growth of Bangladesh. Bangladeshi leather processing industries are facing the challenges of structured sustainable manufacturing practices. 
Scientific knowledge and research may help Bangladeshi companies to adopt sustainable manufacturing practices (Rosen and Kishawy, 2012).

Considering the importance of sustainable manufacturing practices and the circular economy (Muduli et al., 2013; Ying and Li-jun, 2012), this paper aims to analyze drivers in the context of the leather industry of Bangladesh. Thus, this paper contributes to the sustainable supply chain management literature as follows:

- We identify most important drivers to adopt sustainable manufacturing practices in the leather industry of Bangladesh.

- We propose a framework to examine and evaluate the drivers to sustainable manufacturing practices using graph theory and matrix approach (GTMA).

This paper is structured as follows: Section 2 highlights materials, including the leather industry of Bangladesh, sustainable manufacturing practices and the concept of the circular economy. Drivers to sustainable manufacturing practices are highlighted in Section 3. Research methodology is explained in Section 4. Section 5 explains the solution methodology. An industrial case study is discussed in Section 6. Section 7 details the results discussions and managerial implications. Finally, conclusions and recommendations for future research are discussed in Section 8.

\section{Materials}

\subsection{The leather industry of Bangladesh}

The leather industry plays a vital role in the economy of Bangladesh. The Bangladeshi leather industry is the second largest export earner after the apparel sector (Moktadir et al., 2017). The government has declared this sector to be a priority sector. The leather industry has the potential to create employment and entrepreneurship by creating an export-oriented business opportunities. As per the statistics given by Export Promotion Bureau of Bangladesh (EPB), for the financial year 2011-12 the leather sector grew by $17.5 \%$ and earned US $\$ 765$ million in revenue, of which US \$434.8 million was earned from footwear and leather products. This constituted almost $57 \%$ of the total revenue of the sector. In 2012-13, Bangladesh earned almost US \$1 billion as per the data of EPB which represented $28 \%$ growth from the previous year. In the following fiscal year 2013-14 Bangladesh earned US \$ 1.12 billion from exporting leather goods and resulted in $32 \%$ growth from the previous year. In the following year, 2014-15, Bangladesh earned US $\$ 1.13$ billion and the growth was 0.56\% (EPB Report, 2015). The major importing countries of Bangladeshi footwear and other leather products are Germany, China, Japan, USA, Spain, Italy, France, UK, and UAE (Hoque and Clarke, 2013).

The leather industry of Bangladesh includes 220 tanneries, 3,500 Small and Medium Enterprises (SME) and 110 large firms which together control almost $90 \%$ of the export market. According to EPB, the Bangladesh leather industry meets $10 \%$ of the total world leather market. This sector employs more than 85,000 people, including a significant number of women (Technical Report, 2013). Bangladesh has a large domestic raw material base 
(cattle) and is moving toward building a sustainable manufacturing environment to supply the local and international market. In leather industry, up to $90 \%$ value addition is possible.

\subsubsection{A brief of small-scale and large-scale leather companies}

Small scale companies are those whose annual production is equal to or less than 5 million square feet of leather. Large-scale companies are those which produce more than 10 million square feet of leather per annum (Vogel et al., 2012).

There are about 2500 leather products' manufacturing companies in Bangladesh. Also, there are about 100 small to medium type leather products' manufacturing companies which are directly involved in producing leather products and meeting the national and international demand.

\subsection{Sustainable manufacturing practices}

Sustainable manufacturing practices are very important in a manufacturing industry (Tan et al., 2011; Alayón et al., 2017; Shankar et al., 2017). Sustainable manufacturing is the process of creating manufactured products through economically sound processes that minimize the total negative impact on the environment while ensuring the conservation of energy and resources (Schrader and Thøgersen, 2011; Govindan et al., 2015). Sustainable manufacturing includes producing sustainable products. It paves the way for employment, community and product safety and security, ensuring a sustainable environment (Smith and Ball, 2012; Gupta et al., 2016; Bellantuono et al., 2017). Many industries around the world now realize the substantial financial and environmental benefits of sustainable manufacturing practices (Sheldon, 2014; Peralta Álvarez et al., 2017). Sustainable manufacturing increases growth and global competitiveness. Green manufacturing, reverse logistics, and green supply chain are all integrated parts of sustainable manufacturing (Smith and Ball, 2012). This practice involves the integration of technical feasibility, environmental responsibility and economic viability (Sáez-Martínez et al., 2016). It increases operational efficiency by reducing costs and waste (Ijomah, 2010). Moreover, it creates new customers and increases competitive advantage by protecting and strengthening brand and reputation and by building public trust (Geldermann et al., 2007).

Sustainable manufacturing practices build long-term business viability and success (Wang et al., 2015). They also respond to regulatory constraints and opportunities (Bhanot et al., 2017; Shankar et al., 2017). The Bangladeshi leather industry should move towards creating opportunities by adopting sustainable manufacturing practices in a circular economy. Reuse of products, remanufacturing, cascaded use and recovery are all part of sustainable manufacturing practices and a circular economy (Feng and Joung, 2011). Environmental friendliness, manufacturing cost, waste management, power consumption, operational safety and personal health are some dimensions of sustainability elements of the manufacturing process. The fields of study and action plans for sustainable manufacturing practices cover a variety of areas. Sustainability in business processes, product development, supply chain, production operations, distribution chain and sustainability by remanufacture, recycling, reverse logistics belong to the field of study of sustainable manufacturing (Esmaeilian et al., 
2016; Sáez-Martínez et al., 2016). Sustainable manufacturing practices mean using renewable materials that don't deplete the natural resources, use fewer materials and inputs that are nonhazardous, modify production processes to use less materials and energy, use more efficient transport and logistics systems, design products to be reusable, re-manufacturable, recyclable and biodegradable and work with stakeholders and customers to reduce the environmental impacts of the industry. The adoption of sustainable manufacturing practices in leather industries of Bangladesh will thus lead to competitive advantages.

\subsection{Circular economy}

The circular economy is the concept of an industrial economy in which greater resource productivity is promoted by developing ways to continually re-acquire and reintroduce the discarded assets after the completion of one life cycle (Walter, 2015; Pomponi and Moncaster, 2017). There are two types of value chains. One is a linear value chain and other is the closed loop value chain (Zils, 2014). In a linear value chain, materials are sourced then prepared for manufacturing. When the manufacturing process is completed, manufacturing waste is generated. After manufacturing, products are ready for distribution by logistical systems, which generate logistics waste (Zeqiang and Wenming, 2006). In the subsequent sales and retail steps, packaging waste is generated (Macarthur, 2013). Consumption and usage wastes are generated upon consumption of the products. In the linear value chain scenario, none of the waste streams are further used or re-manufactured.

The circular economy is a closed loop value chain (Preston, 2012). In closed loop value chains, all wastes are collected via the proper channels and returned to the re-manufacturing unit to be reused (Yuan et al., 2006). The circular economy ensures sustainable manufacturing processes and sustainable environmental practices by inherent waste prevention and reduction (Fischer and Pascucci, 2017). A circular economy is the one which is restorative and regenerative by design - it focuses on optimization of the value chain. It is the positive, continuous development process which preserves and enhances natural capital and optimizes resources (Andersen, 2007). There are several types of circular economy business or industrial systems (Walter, 2015). Remanufacturing also belongs to the circular economy where a manufacturer remanufactures the products returned by the customers, and also gives a guarantee of the performance of the remanufactured products. A manufacturer can also offer to repair products in a circular economy (Lewandowski, 2016; Lieder and Rashid, 2016). Take-back management, where the remanufacturer takes back the products after consumption via their own reverse logistics system, may also be a part of a circular economy. A manufacturer can transform or recycle a product into a new material or products (Andrews, 2015). A manufacturer can design waste-free products that can be integrated into fully recyclable loops or biodegradable processes which are called cradle-to-cradle systems in a circular economy (Su et al., 2013). Finally, in a circular economy, a manufacturer can offer to refurbish their own products and return them to their customers (Genovese et al., 2017). In this way, a circular economy goes beyond the boundary of waste prevention and waste reduction to inspire technological, organization and social innovation to create sustainable development within the value chain. 


\subsubsection{Sustainable manufacturing practices in circular economy}

Sustainable manufacturing practices and the circular economy in the leather industry means economic, environmental and social sustainability (Hu et al., 2011). The boundaries of economic sustainability are profitability, future competitiveness and economic impact on the stakeholder. Resource efficiency and harm posed by emissions and waste streams are the parameters of environmental sustainability. Social sustainability concerns health, safety and improved social conditions for employees, and equity within the industry (Lieder and Rashid, 2016).

In the leather industry of Bangladesh, the usual practice is to use hides, skins, chemicals, pigments and dyes as raw materials for leather processing. For leather products, the usual practice is to use finished leathers, adhesives, accessories, thread, and synthetic materials as raw materials. After production, the waste is predominantly solid materials such as tannery sludge, waste leather, lining, adhesive, scrap, etc. (Pringle et al., 2016). In sustainable manufacturing, this waste is returned to the primary stage of the process (Jawahir and Bradley, 2016). In this way, sustainable manufacturing practices reduce waste by reuse, thus maintaining the ideologies of the circular economy. Likewise, after the consumption of the leather products by the customers, the manufacturer can take back the used product by different ways and can utilize them for further remanufacturing processes (Moreno et al., 2014).

In the Bangladeshi leather industry, these practices are not in operation. Therefore, there are huge environmental effects from the operations of the leather industry (Bhowmik, 2013). The wastes and chemicals have huge negative impact on the environment because these are not recycled or treated properly. This has a huge impact on soil and water quality. Adopting sustainable manufacturing practices is therefore crucial for Bangladesh. However, there are many barriers to the implementation of sustainable manufacturing practices. These barriers include technical and economic barriers, lack of knowledge about the circular economy, and insufficient governmental support. However, there are also many drivers to adopt sustainable manufacturing practices and a circular economy for the leather industry of Bangladesh. In this research, we examine different drivers by graph theory and matrix approach (GTMA).

\section{Drivers to sustainable manufacturing practices}

In this section, we discuss the drivers and sub-drivers of sustainable manufacturing practices in the context of the circular economy.

\subsection{Knowledge about Circular Economy (KCE)}

The circular economy plays an important role in sustainable manufacturing practices (Lorek and Spangenberg, 2014). It can be regarded as an enabler or driver for the implementation of sustainable manufacturing practices in the leather industry of Bangladesh. The circular economy is an important issue because it creates lots of energy by preventing lots of waste. Knowledge of the circular economy is critical (Programme des Nations Unies pour l'environnement, 2011). Knowledge of the circular economy is a powerful driver for 
sustainable manufacturing practices. There are also many sub-drivers of this category. Training and education are both extremely important for gaining knowledge about the circular economy. Training is a powerful tool (Siemieniuch et al., 2015), and education by formal or informal means can play a vital role in gaining knowledge. Importance should be placed on the availability of information. As most of the research on the circular economy has been based on developed countries, there is scarcity of available information on the subject of the circular economy for developing countries. Scientific knowledge and research on this topic based on the scenario of the leather industry of Bangladesh will fill this gap in the knowledge.

Employee involvement and motivation from different industries can be a driving force to gain knowledge on the circular economy (Diabat and Govindan, 2011). The employees of an industry undertake most manufacturing level tasks. They can understand and explain the current state of the industry. Thus, if employees come forward and take the initiative to inform the top management of the benefit of a circular economy, then both the employees and the top management can obtain information on this topic and this will be a driving factor.

There are many sectors in a supply chain. Sustainability of manufacturing practices should be maintained by and through different sectors of the supply chain. Knowledge sharing in the supply chain, therefore, plays a vital role in gaining knowledge on the circular economy (Mittal and Sangwan, 2014). Waste prevention can be implemented in every sector of the supply chain, which will be the ultimate target of sustainable manufacturing practices in the circular economy. If this knowledge is not shared by stakeholders of different sectors of the chains, it is therefore not possible to gain a complete understanding of this topic (Cordoba and Veshagh, 2013). Hence, sharing knowledge is very important for sustainable manufacturing practices.

Concerns about environmental impact and the state of the environment by the leather industry of Bangladesh and by the regulatory departments of the government of Bangladesh will increase the knowledge of both the top management of the industries and of government authorities. Scientific knowledge and research will give a clear idea of the environmental impacts. Thus, knowledge on the circular economy, attained by different means and ways, will work as a strong driver to adopting sustainable manufacturing practices in the leather industry of Bangladesh.

\subsection{Customer Awareness (CA)}

Customer awareness is one of the most important drivers to sustainable manufacturing practices in a circular economy (Siemieniuch et al., 2015). The pressure from the customer side to change the model from a linear economy to a circular economy is constantly intensifying. The customers are becoming increasingly aware of and concerned about environmental issues. Environmental collaboration with the customers is an important driver in this regard, as customers are seeking environment friendly products. They choose environment friendly products because they are getting information about this from the government or via increased public awareness. 
Global climate pressure and ecological scarcity of resources are perhaps the two most important drivers to sustainable manufacturing practices of a circular economy (Kulatunga et al., 2013). The world is becoming more and more aware of the environmental need to create a sustainable economy for future generations. It is obvious that the world is facing a scarcity of resources because of high consumption and the current prevailing linear economy. International organizations related to environmental sustainability are putting pressure on developing countries to adopt sustainable manufacturing practices and circular economies that will prevent ecological scarcity of resources. If sustainable manufacturing practices are not adopted in a developing country like Bangladesh, we will face ecological scarcity of resources with potentially irreversible environmental impacts.

Another important driver is community pressure which is a powerful tool (Siemieniuch et al., 2015). There are lots of societies and associations working on promoting the sustainable environment. They can put perhaps the most pressure on the industries to take initiatives to adopt sustainable manufacturing practices and a circular economy. They can also encourage the government to make strict laws for the implementation of sustainable manufacturing practices. Customer awareness of green initiatives is also a vital driver of sustainable manufacturing practices and the circular economy (Stock and Seliger, 2016). Customers are very much aware of the benefits of green initiatives. They know the benefits of less carbon emissions to the environment from recycling and remanufacturing processes. They will put pressure on the community, industries and even the government to take steps to adopt sustainable manufacturing practices and a circular economy (Elmualim et al., 2012). Similarly, in the leather industry of Bangladesh, customer awareness will play a vital role as a driver of sustainable manufacturing practices and a circular economy.

\subsection{Leadership and Commitment from Top Management (LCTM)}

Leadership and commitment from the top management is an another important driver towards sustainable manufacturing practices and a circular economy (Siemieniuch et al., 2015). Top management commitment will also play a vital role in the leather industry of Bangladesh with respect to these issues. The top management of industries can take bold initiatives to maintain a sustainable manufacturing environment. Collaboration between organizations is a part of leadership of the top management. The organizations or industries can share ideas and practices. They can also share experiences about sustainable manufacturing practices (Wang and $\mathrm{Bi}, 2013)$. Every industry needs help from other industries. For example, the leather product manufacturing industry needs leather from the leather making industry. Thus, collaboration among related and dependent industries will play an important role in sustainable manufacturing practices.

The world is an economically competitive place. The leather manufacturing industry should thus take steps to create a sustainable manufacturing environment to ensure their competitive advantage (Alayan et al., 2017). Every company in the industry should maintain a minimum standard in manufacturing practices to ensure a competitive and sustainable manufacturing 
environment. There are many competitors in the leather industry in Bangladesh (Hoque and Clarke, 2013). The competitors can impose pressure on themselves to implement sustainable manufacturing practices and a circular economy. Competitor's pressure towards greening can be a crucial driver of sustainable manufacturing practices. As a part of their leadership, top management can play a vital role in introducing cleaner technologies to their company's manufacturing process (Ghazilla et al., 2015). Cleaner technology denotes technologies that ensure less water pollution, less carbon emissions, green transportation, green supply systems and sustainable manufacturing processes in a circular economy (Nowosielski et al., 2007). Leadership through a committed top management can ensure economic benefits for the industries. Economic uncertainties can be anticipated, economic ups and downs can be controlled and economic sustainability can be maintained by the dynamic leadership of the top management. Long-term economic benefits can drive the adoption of sustainable manufacturing practices in the context of leather companies. Therefore, the top management can take initiatives to adopt these processes. Thus, leadership and commitment from the top management of the leather companies of Bangladesh is a strong driver to sustainable manufacturing practices and a circular economy in this industry.

\subsection{Government Support and Legislation (GSL)}

Government support and legislation is an important driver to sustainable manufacturing processes and a circular economy (Agamuthu et al., 2009). In Bangladesh, the government is already places importance on sustainable manufacturing practices in the leather industry as part of new legislation. Environment degradation is occurring in Bangladesh as a result of the lack of sustainable manufacturing practices of the leather companies of Bangladesh. Government support and law enforcement is therefore necessary to ensure sustainable manufacturing practices. Government funding may also assist in the timely implementation of sustainable manufacturing practices in the Bangladeshi leather industry. A Central Effluent Treatment Plant (CETP) can be established in leather processing by utilizing government funding and government support (Mann et al., 2010).

The government can also impose laws regarding reusing and recycling of materials and packaging. Reusing and recycling of materials and packaging is part of the circular economy (Macarthur, 2014). This is considered sustainable manufacturing practice and can work as a good sub-driver of government support and legislation. ISO 14001 certifications ensure the sustainable practices of the manufacturing industries of the world. The Bangladeshi government could legislate for the leather industry of Bangladesh to fulfill the requirements of ISO 14001.

Environmental collaboration with suppliers is an important driver to sustainable manufacturing practices and a circular economy. The suppliers should be aware of the implementation of sustainable manufacturing practices. The government can encourage suppliers to adopt these kinds of measures to ensure product sustainability. The government can also encourage the industry to choose suppliers who will maintain a sustainability standard. The government can also fund the adoption of sustainable manufacturing practices by both suppliers and manufacturers. Hence, all of the drivers need to be addressed during 
sustainable manufacturing and circular economy implementation in the leather industry in Bangladesh. The major drivers and the sub-drivers are summarized in Table A1 (for details see Appendix 1).

\section{Research Methodology}

For the purpose of this study, we have initially reviewed the existing literature on sustainable manufacturing practices and arranged several discussion sessions with industrial and academic experts. From the explanation and brief description of the existing literature and feedback from industrial experts and academic personnel, we have selected the most prominent drivers to sustainable manufacturing practices in the context of the leather industries of Bangladesh. In this research, we have used experts from two leather processing companies and academic institutions from relevant fields. Then we have categorized drivers under four major driver types. After that, we have developed customized interdependency structural configuration among listed drivers. Then we have utilized GTMA for developing the module. During the quantifying of each driver, we have provided the attribute-based rating scale to assign industrial and academic experts. Experts have helped us formulate the matrix with the help of an attribute base rating scale. Then, the permanent function for the formulated matrix for each major driver is evaluated. Finally, we have evaluated the permanent function of the system level matrix. The graphical presentation of the research framework is shown in Fig. 1. 


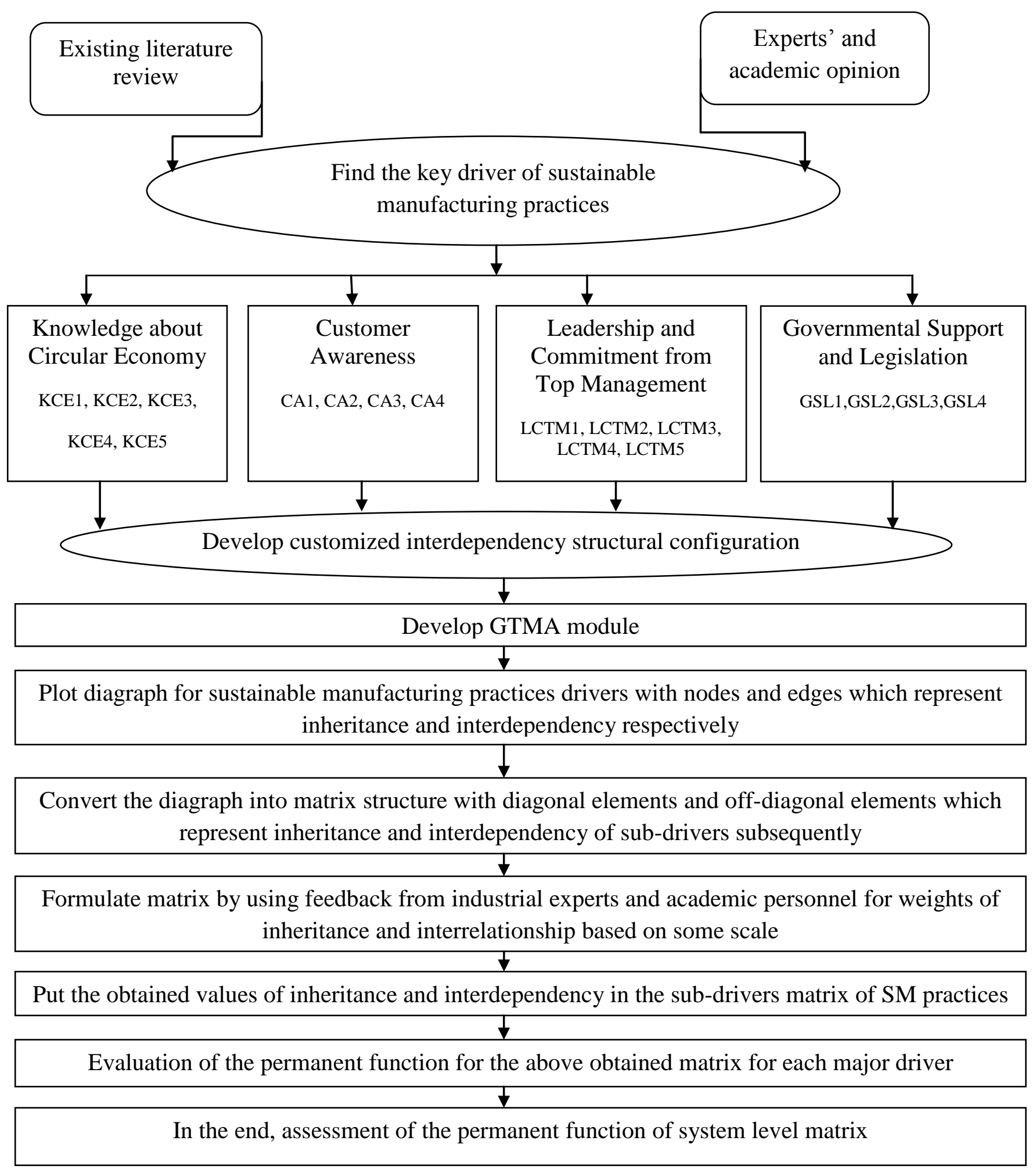

Fig.1. Proposed research framework 


\section{Solution methodology}

We adopt the technique of graph theory with matrix approach (GTMA) to quantify the impact of drivers on sustainable manufacturing practices and a circular economy. As a decisionmaking method, Graph Theory and Matrix Approach (GTMA) offers a generic, simple way to make a decision with less computation. The theorems and algorithms of graph theory allow one to represent the behavioral properties of the system. GTMA representations have proved to be useful for modeling and analyzing various kinds of systems and problems in numerous fields of science and technology. A graph is a collection of vertices joined by edges. It is an ordered pair $\mathrm{G}=(\mathrm{V}, \mathrm{E})$ comprising a set $\mathrm{V}$ which is a set of vertices or nodes or points and a set $\mathrm{E}$ of edges or lines which are all 2-element subsets of $\mathrm{V}$. Three steps are required to construct a GTMA model. Step one is a directed graph (digraph) representation; the second step is a matrix representation, and the last and third step is a permanent function representation. The index value is obtained by calculating the permanent values of the multinomial. This index value can be used for pair-wise comparison, ranking and optimum value selection.

The GTMA model is famous among the researchers. This model is widely implemented in areas of manufacturing science, i.e. improving machining performance (Seymouretal.,2005), flexible manufacturing systems (Bollobas, 1999) and restructuring a manufacturing system (Seymour et al., 2005). Several authors applied GTMA method which includes equipment selection using integrated fuzzy Analytical Hierarchy Process (AHP) and a GTMA method (Fathi et al., 2013), evaluation of the performance of Total Quality Management (TQM) (Kulkarni, 2005) and investigation of the role of human factors in TQM through GTMA (Grover et al., 2004).

Best-worst multi-criteria decision making (Rezaei, 2015), Analytic Network Process (ANP), Analytical Hierarchical Process (AHP) and Structural Equation Modeling (SEM), technically provide similar results. However, these pair-wise comparison techniques do not capture the interdependence of variables. An additional calculation is required in order for AHP to capture interdependency. ANP fails to capture hierarchical structures, though it does capture interrelations among the variables (Saaty, 2004). SEM is a multivariable statistical analysis tool that analyzes structural relations among the variables.

GTMA has no such limitations. However, this method is unable to show interactions among the sub-factors and thus cannot be processed to a mathematical equation for the next step assessment. GTMA serves our current objective best to allow quantifying the impact of drivers of sustainable manufacturing in the leather industry of Bangladesh.

\section{An industrial case study}

Our adopted decision-making approach has been implemented in a real case study and used to assess and quantify the drivers of sustainable manufacturing practices and the circular economy in two leather processing companies in Bangladesh. To identify the most relevant drivers of sustainable manufacturing practices, we review the existing literature and list out most important drivers with the help of four experts. Two experts are taken from large scale 
leather processing companies, one from a small-scale leather processing company and one from an academic field. They have sufficient experience in supply chain management, environmental sustainability, green supply chain and green logistics. They have helped to quantify the drivers of sustainable manufacturing practices in the circular economy context. For the quantification of drivers, we have used the importance scale proposed by Muduli et al., (2013). This relative importance of attributes $\left(r_{i j}\right)$ is formulated on the basis of weightings. In this research, attributes are identified and the corresponding value of permanent, $F_{i}$ is calculated with the help of assigned experts. The available attribute weight is assigned for comparing the drivers and sub-drivers in two leather industries. The attribute and assigned weightings are given in Table 1. The cause-effect relation among drivers is shown in Fig. 2.

Table 1: Attributes and assigned weightings of attribute $\left(r_{i j}\right)$

\begin{tabular}{|l|c|c|}
\hline \multirow{2}{*}{ Class description } & \multicolumn{2}{c|}{ Relative importance of attributes } \\
\cline { 2 - 3 } & $r_{i j}$ & $r_{j i}=10-r_{i j}$ \\
\hline Two properties are of equal importance & 6 & 5 \\
\hline One property is slightly more important & 7 & 4 \\
\hline One property is very importance over the other & 8 & 2 \\
\hline One property is the most important over the other & 9 & 1 \\
\hline One property is extremely important over the other & 10 & 0 \\
\hline $\begin{array}{l}\text { One property is exceptionally important over the } \\
\text { other }\end{array}$ & & \\
\hline
\end{tabular}

The graph theory technique with a matrix approach is a strong model which can help to quantify the effect of sub-drivers of sustainable manufacturing practices and the circular economy. In this research, GTMA is used to transfer the effect of drivers into numerical values. The transformation process enables an effective comparison of the different subdrivers.

The application of graph theory and a matrix approach is well established in the literature (Kaur et al., 2006; Muduli et al., 2013; Pishvaee and Rabbani, 2011; Rao, 2006; Wagner and Neshat, 2010, 2010) and can help to analyze various types of problems which are generally impossible in a real life system. The methodology of GTMA is:

1. Identification of the sub-drivers affecting the main drivers of sustainable manufacturing practices and a circular economy taking into account relative interdependencies among those sub-drivers.

2. Establishing interdependency digraphs among identified drivers and sub-drivers.

3. Conversion of the interdependency digraphs into matrices using equation (1).

4. Conversion to a parametric function of these formulated matrices using equation (2). Before calculation of the parameter of the matrices, formulate the matrices with the 
help of expert opinions and scale the value of matrices from 1-5, where 1 indicates very weak interdependency and value 5 indicates very strong interdependency.

5. Calculation of the corresponding parameter, which is generally a single numerical value as obtained from Table 1.

6. Undertake the theoretical best value calculation and theoretical worst value calculation for two leather companies adopting sustainable manufacturing practices and a circular economy.

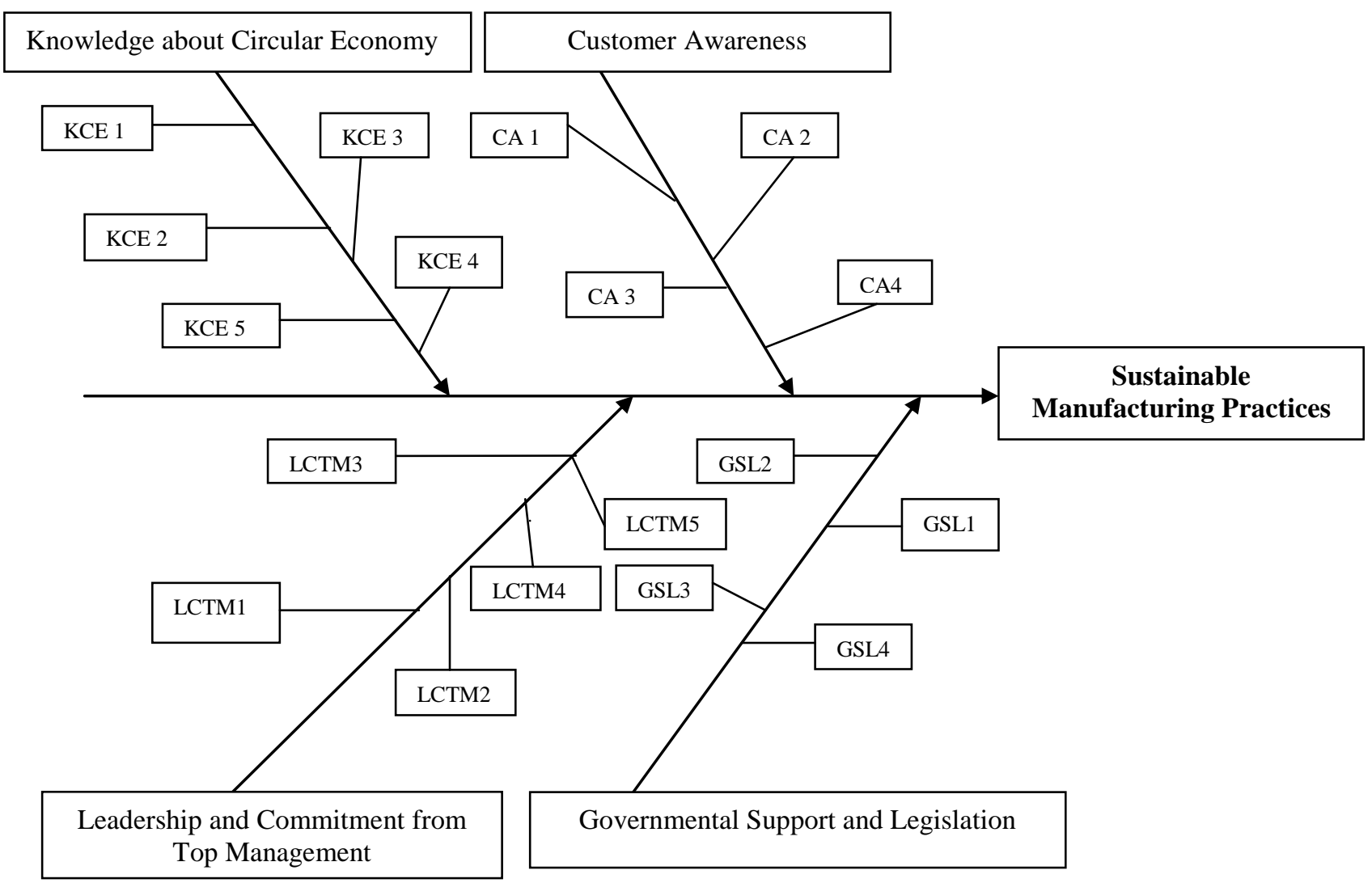

Fig.2.Diagram of cause and effect representation

\subsection{Behavioral digraph}

A directed graph is used to represent the behavioral relationship between main drivers in terms of nodes and edges. In this research, we have used four major drivers. The behavioral relationship between the four major drivers is thus shown in Fig. 3 and the behavioral diagraph of customer awareness (CA) is shown in Fig. 4. In this research, nodes indicate main drivers and edges indicate the interactions between them. Fi indicates the major drivers and $r_{i j}$ shows the degree of interdependence of the $j^{\text {th }}$ driver on the $i^{\text {th }}$ driver. In Fig. 3, $r_{i j}$ is depicted as a directed edge from node $i$ to node $j$. The nodes $F_{1}^{1}, F_{2}^{1}, F^{1}{ }_{3}, F_{4}^{1}$ in Fig. 3 indicate the major drivers and $r_{i j}$ indicates the interdependences among major drivers. Similarly in Fig. 4, $F^{2}{ }_{1}, F_{2}^{2}, F_{3}^{2}, F_{4}^{2}$ indicate the sub-drivers of customer awareness (CA) and 
$r_{i j}$ indicates the interdependencies among sub-drivers to the adoption of sustainable manufacturing practices and a circular economy.

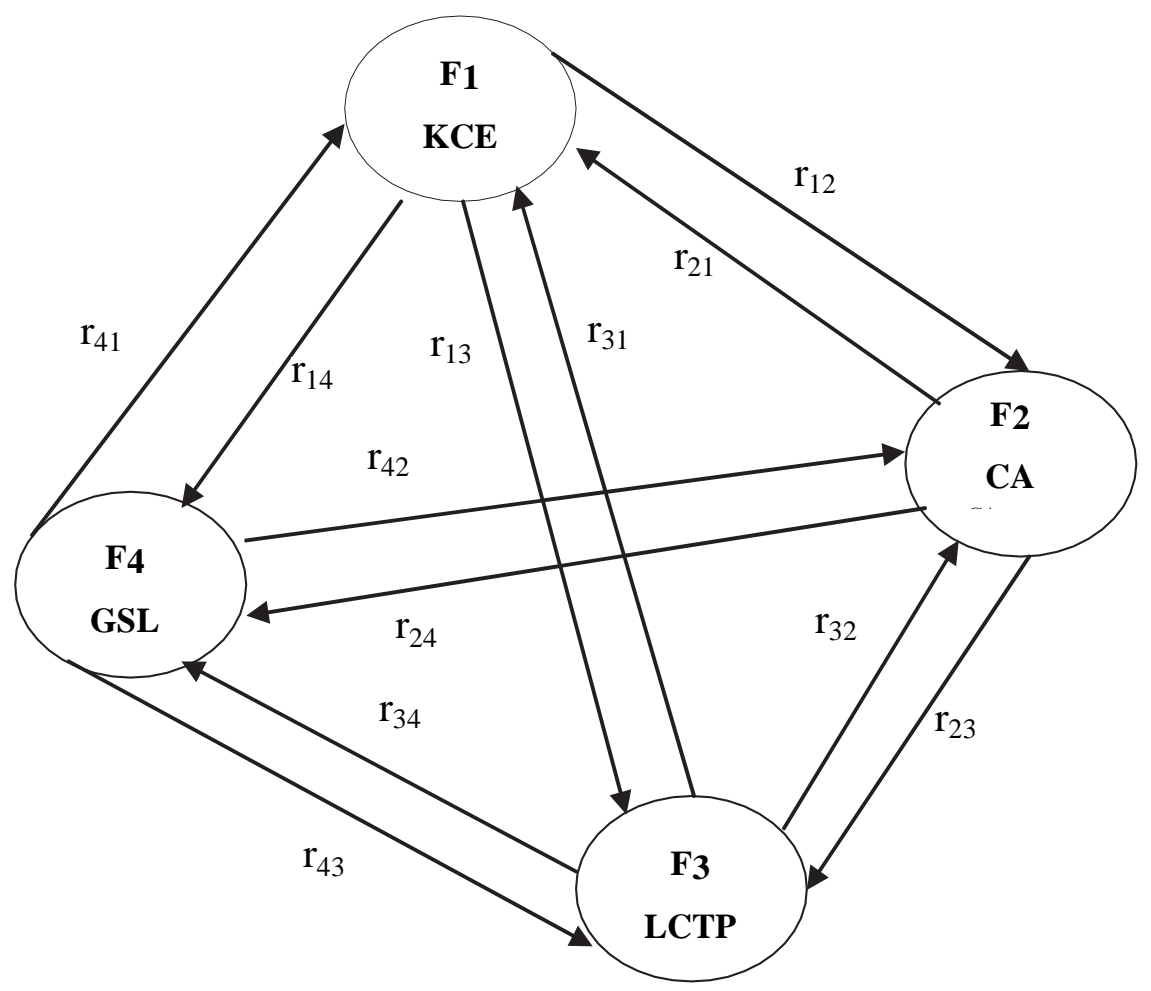

Fig. 3. Behavioral diagraph

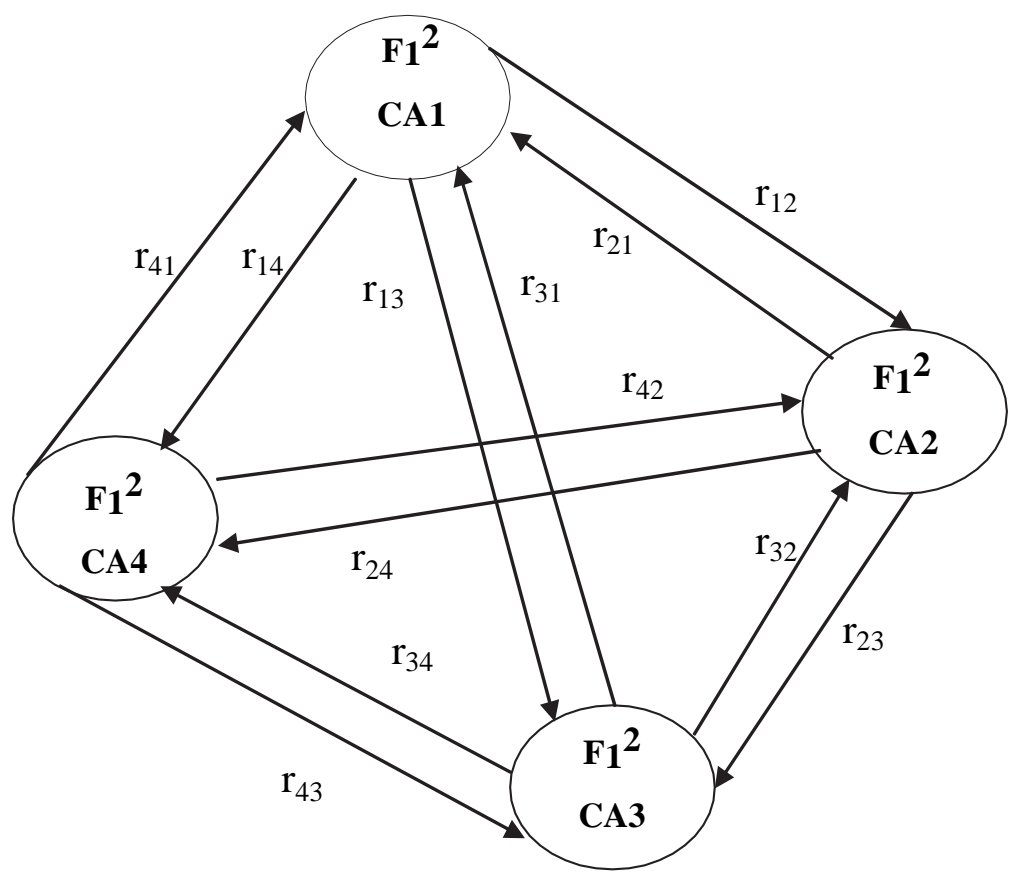

Fig. 4. Behavioral diagraph for driver Customer Awareness (CA) 


\subsection{Matrix representation}

The diagraphs in Figs. 3 and $\mathbf{4}$ are representative of the matrix. This constructive $4 x 4$ matrix indicates the four main drivers of sustainable manufacturing practices and a circular economy. The explicit matrix is:

$$
S M P=\left(\begin{array}{llll}
F_{1} & r_{12} & r_{13} & r_{14} \\
r_{21} & F_{2} & r_{23} & r_{24} \\
r_{31} & r_{32} & F_{3} & r_{34} \\
r_{41} & r_{42} & r_{43} & F_{4}
\end{array}\right)
$$

Where $F_{i}(\mathrm{i}=1,2,3,4)$ are the values of the major drivers, represented by the matrix nodes, and $r_{i j}$ is the relative importance of the $i^{\text {th }}$ driver to the $j^{\text {th }}$ driver, represented by the edge $r_{i j}$.

$$
\operatorname{Per}\left(F_{1}\right)=\operatorname{Per}(K C E)=\left(\begin{array}{ccccc}
F_{1}^{1} & r_{12}^{1} & r_{13}^{1} & r_{14}^{1} & r_{15}^{1} \\
r_{21}^{1} & F_{2}^{1} & r_{23}^{1} & r_{24}^{1} & r_{25}^{1} \\
r_{31}^{1} & r_{32}^{1} & F_{3}^{1} & r_{34}^{1} & r_{35}^{1} \\
r_{41}^{1} & r_{42}^{1} & r_{43}^{1} & F_{4}^{1} & r_{45}^{1} \\
r_{51}^{1} & r_{52}^{1} & r_{53}^{1} & r_{54}^{1} & F_{5}^{1}
\end{array}\right)
$$

where $\boldsymbol{F}_{\boldsymbol{1}}{ }^{\mathbf{1}}, \boldsymbol{F}_{\mathbf{2}}{ }^{\mathbf{1}}, \boldsymbol{F}_{\mathbf{3}}{ }^{\mathbf{1}}, \boldsymbol{F}_{\mathbf{4}}{ }^{\mathbf{1}}, \boldsymbol{F}_{\mathbf{5}}{ }^{\mathbf{l}}$ represent KCE 1, KCE 2, KCE 3, KCE 4, KCE 5 respectively.

$$
\operatorname{Per}\left(F_{2}\right)=\operatorname{Per}(C A)=\left(\begin{array}{cccc}
F_{1}^{2} & r_{12}^{2} & r_{13}^{2} & r_{14}^{2} \\
r_{21}^{2} & F_{2}^{2} & r_{23}^{2} & r_{24}^{2} \\
r_{31}^{2} & r_{32}^{2} & F_{3}^{2} & r_{34}^{2} \\
r_{41}^{2} & r_{42}^{2} & r_{43}^{2} & F_{4}^{2}
\end{array}\right)
$$

Similarly, $\boldsymbol{F}_{1}{ }^{1}, \boldsymbol{F}_{2}{ }^{1}, \boldsymbol{F}_{3}{ }^{1}, \boldsymbol{F}_{4}{ }^{1}$ represent CA1, CA2, CA3, CA4 subsequently.

$$
\operatorname{Per}\left(F_{3}\right)=\operatorname{Per}(L C T P)=\left(\begin{array}{ccccc}
F_{1}^{1} & r_{12}^{1} & r_{13}^{1} & r_{14}^{1} & r_{15}^{1} \\
r_{21}^{1} & F_{2}^{1} & r_{23}^{1} & r_{24}^{1} & r_{25}^{1} \\
r_{31}^{1} & r_{32}^{1} & F_{3}^{1} & r_{34}^{1} & r_{35}^{1} \\
r_{41}^{1} & r_{42}^{1} & r_{43}^{1} & F_{4}^{1} & r_{45}^{1} \\
r_{51}^{1} & r_{52}^{1} & r_{53}^{1} & r_{54}^{1} & F_{5}^{1}
\end{array}\right)
$$

Here also $\boldsymbol{F}_{1}{ }^{1}, \boldsymbol{F}_{2}{ }^{1}, \boldsymbol{F}_{3}{ }^{1}, \boldsymbol{F}_{4}{ }_{4}, \boldsymbol{F}_{5}{ }^{1}$ represent LCTP1, LCTP2, LCTP3, LCTP4, LCTP5

respectively. 


$$
\operatorname{Per}\left(F_{4}\right)=\operatorname{Per}(G S L)=\left(\begin{array}{cccc}
F_{1}^{2} & r_{12}^{2} & r_{13}^{2} & r_{14}^{2} \\
r_{21}^{2} & F_{2}^{2} & r_{23}^{2} & r_{24}^{2} \\
r_{31}^{2} & r_{32}^{2} & F_{3}^{2} & r_{34}^{2} \\
r_{41}^{2} & r_{42}^{2} & r_{43}^{2} & F_{4}^{2}
\end{array}\right)
$$

Similarly $\boldsymbol{F}_{1}{ }^{1}, \boldsymbol{F}_{2}{ }^{1}, \boldsymbol{F}_{3}{ }^{1}, \boldsymbol{F}_{4}{ }^{1}$ represent GSL1, GSL2, GSL3, GSL4 subsequently.

\subsection{Permanent representation}

The permanent matrix equation is a standard matrix function. This is used in combinatorial mathematics (Jurkat and Ryser, 1966). The mathematical explanation for a permanent function which corresponds to four matrix element digraphs by using the Jurkat and Ryser formula is explained by the following equations:

$$
\begin{aligned}
& \operatorname{Per}(F)=\prod_{i=1}^{4} F_{i}+\sum_{i} \sum_{j} \sum_{k} \sum_{l} r_{i j} r_{j i} F_{k} F_{l}+\sum_{i} \sum_{j} \sum_{k} \times \sum_{l}\left(r_{i j} r_{j k} r_{k i}+r_{i k} r_{k j} r_{j i}\right) F_{l}+ \\
& {\left[\sum_{i} \sum_{j} \sum_{k} \sum_{l}\left(r_{i j} r_{j i}\right) \times\left(r_{k l} r_{l k}\right)+\sum_{i} \sum_{j} \sum_{k} \sum_{l}\left(r_{i j} r_{j k} r_{k l} r_{l i}+r_{i l} r_{l k} r_{k j} r_{j i}\right)\right] .}
\end{aligned}
$$

The permanent expression contains terms arranged in an $n+1$ grouping. Therefore, $n=4$ and there are five groupings whose physical significance is expressed as follows:

$>$ The $1^{\text {st }}$ grouping contains only one term and represents the interaction among the four major drivers of sustainable manufacturing practices, that is $F_{1}, F_{2}$, $F_{3}, F_{4}$.

$>$ The $2^{\text {nd }}$ grouping is not shown here as the self-loop in the diagraph is absent.

$>$ The $3^{\text {rd }}$ grouping has two terms of which each term represents two-driver interdependence (i.e., $r_{i j} r_{j i}$ ) and a measure of the remaining drivers, $n$-2 (i.e., 2 here).

$>$ In the $4^{\text {th }}$ grouping, each term represents a set of three driver interdependences $r_{i j} r_{j k} r_{k i}$ or its pair $r_{i k} r_{k j} r_{j i}$ and a measure of the remaining drivers, $n$-3 (i.e., 1 here).

$>$ The fourth grouping terms are arranged in two subgroups. The $1^{\text {st }}$ subgrouping is a set of two two-driver interdependences (i.e., $r_{i j} r_{j i}$ and $r_{k l} r_{l k}$ ) and measurement of remaining drivers, $n-4$ (i.e., 0 ). The second sub-grouping is a set of four driver interdependences (i.e., $r_{i j} r_{j k} r_{k l} r_{l i}$ and $r_{i l} r_{l k} r_{k j} r_{j i}$ ) and a measure of remaining drivers, $n-4$ (i.e., 0 ).

These rules result in the following matrix for CA: 
$\operatorname{Per}^{S S}(C A)=\left(\begin{array}{cccc}F_{1}^{2} & r_{12}^{2} & r_{13}^{2} & r_{14}^{2} \\ r_{21}^{2} & F_{2}^{2} & r_{23}^{2} & r_{24}^{2} \\ r_{31}^{2} & r_{32}^{2} & F_{3}^{2} & r_{34}^{2} \\ r_{41}^{2} & r_{42}^{2} & r_{43}^{2} & F_{4}^{2}\end{array}\right)=\left(\begin{array}{cccc}3 & 5 & 6 & 6 \\ 5 & 3 & 6 & 4 \\ 4 & 4 & 4 & 5 \\ 4 & 6 & 5 & 4\end{array}\right)=$ This matrix can be explained by the following ways;

$F_{1}^{2} F_{2}^{2} F_{3}^{2} F_{4}^{2}+\left(r_{12}^{2} r_{21}^{2} F_{3}^{2} F_{4}^{2}+r_{13}^{2} r_{31}^{2} F_{2}^{2} F_{4}^{2}+r_{14}^{2} r_{41}^{2} F_{2}^{2} F_{3}^{2}+r_{23}^{2} r_{32}^{2} F_{1}^{2} F_{4}^{2}+r_{24}^{2} r_{42}^{2} F_{1}^{2} F_{3}^{2}+r_{34}^{2} r_{43}^{2} F_{1}^{2} F_{2}^{2}\right)$

$+\left(r_{23}^{2} r_{34}^{2} r_{42}^{2} F_{1}^{2}+r_{24}^{2} r_{43}^{2} r_{32}^{2} F_{1}^{2}+r_{13}^{2} r_{34}^{2} r_{41}^{2} F_{2}^{2}+r_{14}^{2} r_{43}^{2} r_{31}^{2} F_{2}^{2}+r_{12}^{2} r_{24}^{2} r_{41}^{2} F_{3}^{2}+r_{14}^{2} r_{42}^{2} r_{21}^{2} F_{3}^{2}+r_{12}^{2} r_{23}^{2} r_{31}^{2} F_{4}^{2}+r_{13}^{2} r_{32}^{2} r_{21}^{2} F_{4}^{2}\right)$

$+\left(r_{12}^{2} r_{21}^{2} r_{34}^{2} r_{43}^{2}+r_{13}^{2} r_{31}^{2} r_{24}^{2} r_{42}^{2}+r_{14}^{2} r_{41}^{2} r_{23}^{2} r_{32}^{2}+r_{12}^{2} r_{23}^{2} r_{34}^{2} r_{41}^{2}+r_{14}^{2} r_{43}^{2} r_{32}^{2} r_{21}^{2}+r_{13}^{2} r_{34}^{2} r_{42}^{2} r_{21}^{2}+r_{12}^{2} r_{24}^{2} r_{43}^{2} r_{31}^{2}+r_{14}^{2} r_{42}^{2} r_{23}^{2} r_{31}^{2}+r_{13}^{2} r_{32}^{2} r_{24}^{2} r_{41}^{2}\right)$

Replacing the numerical values for computing permanent matrix CA for a small-scale

industry.

$\operatorname{Per}^{S S}(C A)=$

$3 \times 3 \times 4 \times 4+(5 \times 5 \times 4 \times 4+6 \times 4 \times 3 \times 4+6 \times 4 \times 3 \times 4+6 \times 4 \times 3 \times 4+4 \times 6 \times 3 \times 4+5 \times 5 \times 3 \times 3)+(6 \times 5 \times 6 \times 3+4 \times 5 \times$

$4 \times 3+6 \times 5 \times 4 \times 3+6 \times 5 \times 4 \times 3+5 \times 4 \times 4 \times 4+6 \times 6 \times 5 \times 4+5 \times 6 \times 4 \times 4+6 \times 4 \times 5 \times 4)+(5 \times 5 \times 5 \times 5+6 \times 4 \times 4 \times 6+$

$6 \times 4 \times 6 \times 4+5 \times 6 \times 5 \times 4+6 \times 5 \times 4 \times 5+6 \times 5 \times 6 \times 5+5 \times 4 \times 5 \times 4+6 \times 6 \times 6 \times 4+6 \times 4 \times 4 \times 4)=10946$.

Similarly, the permanent matrix of the other drivers can be computed for large-scale and small-scale companies.

$\operatorname{Per}^{L S}(C A)=\left(\begin{array}{llll}2 & 4 & 6 & 5 \\ 6 & 2 & 5 & 3 \\ 4 & 5 & 3 & 6 \\ 5 & 7 & 4 & 4\end{array}\right)=9769$

where $\operatorname{Per}^{\mathrm{SS}}(\mathrm{CA})$ shows the index value for the customer awareness driver for small scale leather companies and $\operatorname{Per}^{\mathrm{LS}}(\mathrm{CA})$ shows the index value for the customer awareness driver for large-scale leather companies in Bangladesh.

\section{Other index values are given as follows:}

Index value for knowledge about circular economy

$$
\operatorname{Per}^{S S}(K C E)=\left(\begin{array}{lllll}
4 & 4 & 6 & 5 & 6 \\
6 & 5 & 6 & 5 & 6 \\
4 & 4 & 4 & 4 & 6 \\
5 & 5 & 6 & 4 & 5 \\
4 & 4 & 4 & 5 & 5
\end{array}\right)=320720
$$




$$
\operatorname{Per}^{L S}(K C E)=\left(\begin{array}{lllll}
3 & 5 & 4 & 5 & 5 \\
5 & 3 & 4 & 4 & 3 \\
6 & 6 & 2 & 4 & 3 \\
5 & 6 & 6 & 3 & 5 \\
5 & 7 & 7 & 5 & 2
\end{array}\right)=218259
$$

Index value for lack of commitment from top management

$$
\begin{aligned}
& \operatorname{Per}^{S S}(\text { LCTP })=\left(\begin{array}{lllll}
5 & 7 & 7 & 6 & 6 \\
3 & 3 & 7 & 6 & 6 \\
3 & 3 & 2 & 6 & 7 \\
4 & 4 & 4 & 4 & 5 \\
4 & 4 & 3 & 5 & 5
\end{array}\right)=265254 \\
& \operatorname{Per}^{L S}(\text { LCTP })=\left(\begin{array}{lllll}
5 & 6 & 6 & 5 & 8 \\
4 & 4 & 6 & 7 & 7 \\
4 & 4 & 3 & 4 & 8 \\
5 & 3 & 6 & 5 & 8 \\
2 & 3 & 2 & 2 & 2
\end{array}\right)=210748
\end{aligned}
$$

Index value for driver of governmental support and legislation

$$
\begin{aligned}
\operatorname{Per}^{S S}(G S L) & =\left(\begin{array}{llll}
5 & 8 & 6 & 7 \\
2 & 2 & 5 & 8 \\
4 & 5 & 4 & 6 \\
3 & 2 & 4 & 3
\end{array}\right)=9100 \\
\operatorname{Per}^{L S}(G S L) & =\left(\begin{array}{llll}
4 & 6 & 5 & 6 \\
4 & 3 & 4 & 5 \\
5 & 6 & 4 & 4 \\
4 & 5 & 6 & 3
\end{array}\right)=10946
\end{aligned}
$$

The sustainable manufacturing practices (SMP) value can be computed by assessing the permanent value of matrix SMP.

$$
\operatorname{Per}\left(S M P^{S S}\right)=\left(\begin{array}{cccc}
320720 & 7 & 7 & 8 \\
3 & 10946 & 4 & 3 \\
3 & 6 & 265254 & 2 \\
2 & 7 & 8 & 9100
\end{array}\right)=84.74 \times 10^{17}
$$


$\operatorname{Per}\left(S M P^{L S}\right)=\left(\begin{array}{cccc}218259 & 7 & 7 & 6 \\ 3 & 9769 & 4 & 3 \\ 3 & 6 & 210748 & 4 \\ 4 & 7 & 6 & 10946\end{array}\right)=49.19 \times 10^{17}$

6.4 Calculation of the theoretical best value for different major drivers for sustainable

manufacturing practices

The theoretical best value for a major SMP driver is acquired when the inheritance of all its

sub-drivers have the best value (here 1). The best value for driver KCE and LCTP for small-

scale leather companies is:

$\operatorname{Per}\left(B_{K C E / L C T P}^{S S}\right)=\left(\begin{array}{ccccc}1 & 5 & 5 & 5 & 5 \\ 5 & 1 & 5 & 5 & 5 \\ 5 & 5 & 1 & 5 & 5 \\ 5 & 5 & 5 & 1 & 5 \\ 5 & 5 & 5 & 5 & 1\end{array}\right)=168376$

In the similar way, the best value for driver KCE and LCTP for large-scale leather companies

is:

$$
\operatorname{Per}\left(B_{K C E / L C T P}^{L S}\right)=\left(\begin{array}{ccccc}
1 & 5 & 5 & 5 & 5 \\
5 & 1 & 5 & 5 & 5 \\
5 & 5 & 1 & 5 & 5 \\
5 & 5 & 5 & 1 & 5 \\
5 & 5 & 5 & 5 & 1
\end{array}\right)=168376
$$

The best value for other drivers such as CA and GSL are calculated similarly as follows: 


$$
\begin{aligned}
& \operatorname{Per}\left(B_{C A / G S L}^{S S}\right)=\left(\begin{array}{llll}
1 & 5 & 5 & 5 \\
5 & 1 & 5 & 5 \\
5 & 5 & 1 & 5 \\
5 & 5 & 5 & 1
\end{array}\right)=6776 \\
& \operatorname{Per}\left(B_{C A / G S L}^{L S}\right)=\left(\begin{array}{llll}
1 & 5 & 5 & 5 \\
5 & 1 & 5 & 5 \\
5 & 5 & 1 & 5 \\
5 & 5 & 5 & 1
\end{array}\right)=6776
\end{aligned}
$$

\subsection{Calculation of the theoretical worst value for different drivers}

Technically, the theoretical worst value for a driver is acquired when the inheritance of all its sub-drivers have its worst value, i.e., maximum value (5). The worst value for KCE and LCTP drivers for small-scale leather companies is:

$$
\operatorname{Per}\left(W_{K C E / L C T P}^{S S}\right)=\left(\begin{array}{ccccc}
5 & 5 & 5 & 5 & 5 \\
5 & 5 & 5 & 5 & 5 \\
5 & 5 & 5 & 5 & 5 \\
5 & 5 & 5 & 5 & 5 \\
5 & 5 & 5 & 5 & 5
\end{array}\right)=375000
$$

We can also compute the worst value for large-scale leather industries in a similar way is:

$$
\operatorname{Per}\left(W_{K C E / L C T P}^{L S}\right)=\left(\begin{array}{ccccc}
5 & 5 & 5 & 5 & 5 \\
5 & 5 & 5 & 5 & 5 \\
5 & 5 & 5 & 5 & 5 \\
5 & 5 & 5 & 5 & 5 \\
5 & 5 & 5 & 5 & 5
\end{array}\right)=375000
$$

The worst values for the other drivers are:

$$
\operatorname{Per}\left(W_{C A / G P L}^{S S}\right)=\left(\begin{array}{llll}
5 & 5 & 5 & 5 \\
5 & 5 & 5 & 5 \\
5 & 5 & 5 & 5 \\
5 & 5 & 5 & 5
\end{array}\right)=15000
$$


$\operatorname{Per}\left(W_{C A / G P L}^{L S}\right)=\left(\begin{array}{cccc}5 & 5 & 5 & 5 \\ 5 & 5 & 5 & 5 \\ 5 & 5 & 5 & 5 \\ 5 & 5 & 5 & 5\end{array}\right)=15000$

Therefore we can compute the SMP index for worst and best value as:

$$
\begin{aligned}
& \operatorname{Per}(B)=\left(\begin{array}{cccc}
168376 & 7 & 7 & 8 \\
3 & 6766 & 4 & 3 \\
3 & 6 & 168376 & 2 \\
2 & 7 & 8 & 6766
\end{array}\right)=12.98 \times 10^{17} \\
& \operatorname{Per}(W)=\left(\begin{array}{cccc}
375000 & 7 & 7 & 6 \\
3 & 15000 & 4 & 3 \\
3 & 6 & 375000 & 4 \\
4 & 7 & 6 & 15000
\end{array}\right)=316.41 \times 10^{17}
\end{aligned}
$$

\section{Comparison}

If the sustainable manufacturing practice driver matrices are identical, any two leather companies selected for comparison purposes will be similar from the perspective of the sustainable manufacturing drivers. However, the drivers of sustainable manufacturing practices are not identical for both scales of leather companies (Grover et al., 2004). Therefore, it is necessary to compute the similarity and dissimilarity of both scales of leather companies. For this purpose, it is necessary to evaluate the coefficient of similarity $C_{s i}$ and dissimilarity $C_{s i}^{\prime}($ Kulkarni, 2005):

$$
C_{s i}=\frac{\left(C_{i j}-B_{i j}\right)}{\left(W_{i j}-B_{i j}\right)}
$$

Here,

$C_{s i}=$ Coefficient of similarity of the $i^{\text {th }}$ driver with the best value.

$B_{i j}=$ Best value of the driver $i$ of the $j^{\text {th }}$ industry.

And, $C_{i j}=$ Current value of the $i^{\text {th }}$ driver of the $j^{\text {th }}$ industry.

$$
C^{\prime}{ }_{s i}=\frac{\left(W_{i j}-C_{i j}\right)}{\left(W_{i j}-B_{i j}\right)}
$$

Here, 
$C^{\prime}{ }_{s i}=$ Coefficient of similarity of the $i^{\text {th }}$ driver with the worst value.

$W_{i j}=$ Worst value of the driver $i$ of the $j^{\text {th }}$ industry.

$C_{d i}$ and $C^{\prime}{ }_{d i}$ are the coefficients of dissimilarity with the best and worst values, respectively.

$C_{d i}=1-C_{s i}$

$C^{\prime}{ }_{d i}=1-C^{\prime}{ }_{s i}$

A smaller, $C_{s i}$ value points out more similarity with the best value. On the contrary, the smaller the value of $C_{s i}$, the less dominant or influential a driver will be, and vice versa.

\section{Comparison between two drivers}

For comparison, consider the two drivers knowledge about the circular economy (KCE) and Governmental Support and Legislation (GSL) of large-scale companies.

$$
\begin{aligned}
& C_{s 1}^{\prime}=\frac{375000-218259}{375000-168376}=0.7586 \\
& C_{s 4}^{\prime}=\frac{15000-10946}{15000-6766}=0.4923
\end{aligned}
$$

Here the coefficient of similarity of driver KCE with the worst value points out that the intensity or strength of driver KCE is less than that of driver GSL for the case study.

\section{Results, discussions and managerial implications}

The calculated index values of the drivers of sustainable manufacturing practices and the circular economy are presented in Table 2. Index values of a particular driver stipulate the degree of its impact during sustainable manufacturing practices and a circular economy with respect to the leather companies of Bangladesh. Higher index values indicate a greater impact of the driver to sustainable manufacturing practices. A lower index value indicates a lower impact (Muduli et al., 2013). The lower Sustainable Manufacturing Practices (SMP) index values indicate that sustainable manufacturing practices have a less positive impact, and the company needs to pay more attention to their adoption along with a circular economy. Higher SMP values indicate that the company does not need to give higher attention to implementing sustainable manufacturing practices.

In this research, the calculated SMP index indicates the fitness of the leather industry to adopt sustainable manufacturing practices and a circular economy. The driver knowledge about the circular economy (KCE) was shown to be the greatest driver to implementing SMP for largescale leather companies of Bangladesh. The value of KCE is closer to the worst value for small-scale compared to large-scale leather companies which indicates that the small-scale industry should take more care during SMP implementation compared to the large-scale leather companies. In the case of best value for $\mathrm{KCE}$, the large-scale companies are closer to 
the best value of the driver, meaning that implementing SMP is easier for large-scale companies.

Table 2: Index values of different drivers for both large- and small-scale leather industries

\begin{tabular}{|l|l|l|l|l|l|}
\hline $\begin{array}{l}\text { Type of } \\
\text { industry }\end{array}$ & $\begin{array}{l}\text { Knowledge } \\
\text { about } \\
\text { Circular } \\
\text { Economy } \\
\text { (KCE) }\end{array}$ & $\begin{array}{l}\text { Customer } \\
\text { Awareness } \\
(\mathrm{CA})\end{array}$ & $\begin{array}{l}\text { Leadership } \\
\text { and } \\
\text { Commitment } \\
\text { from Top } \\
\text { Management } \\
\text { (LCTP) }\end{array}$ & $\begin{array}{l}\text { Governmental } \\
\text { Support and } \\
\text { Legislation } \\
\text { (GSL) }\end{array}$ & $\begin{array}{l}\text { Sustainable } \\
\text { Manufacturing } \\
\text { Practices } \\
\text { Index }\end{array}$ \\
\hline Large scale & 218259 & 9769 & 210748 & 10946 & $49.19 \times 10^{17}$ \\
\hline Small scale & 320720 & 10946 & 265254 & 9100 & $84.74 \times 10^{17}$ \\
\hline Best Value & 168376 & 6766 & 168376 & 6766 & $12.98 \times 10^{17}$ \\
\hline $\begin{array}{l}\text { Worst } \\
\text { Value }\end{array}$ & 375000 & 15000 & 375000 & 15000 & $316.41 \times 10^{17}$ \\
\hline
\end{tabular}

For the driver Customer Awareness (CA), it is clear that the value of CA for large-scale leather companies compared to small-scale companies is closer to the best value, indicating that the driver of CA is more important for large-scale companies adopting SMP.

Another major driver of SMP implementation is Leadership and Commitment from Top Management (LCTP). For this driver, the best value is closer to that of the large-scale leather companies compared to the small-scale companies. This indicates that the driver (LCTP) is more influential for large-scale leather companies. The complexity of the driver LCTP in the case of small-scale companies will be higher than for the large scale companies.

The final major driver is Governmental Support and Legislation (GSL). The best value is closer for the small-scale companies, meaning GSL influences small-scale leather companies' more than large-scale leather companies in Bangladesh because small-scale leather companies need more support from government for the adoption of sustainable manufacturing practices. They do not have sufficient capital - that's why small-scale leather companies can be major beneficiaries if the government provides financial support. Likewise, legislation can give more force to adopting sustainable manufacturing practices in small-scale leather companies compared to large-scale leather companies in the context of Bangladesh.

This research is significant for both large- and small-scale leather companies in Bangladesh in terms of the adoption of sustainable manufacturing practices through considering the drivers identified in this research. To adopt sustainable manufacturing practices in the leather industry, it is necessary to identify sustainable manufacturing implementing drivers. In this study, we have considered four major drivers which have been ranked with the help of GTMA. The comparison among the four divers as well as their index value will be helpful for 
decision makers to concentrate on appropriate drivers during the sustainable manufacturing practices implementing stage.

This research is expected to help decision makers identify various drivers and to explore the exact nature of these drivers to assist implementing sustainable manufacturing practices. Managers of leather-based companies may use this research to understand how sustainable manufacturing practices can be a competitive advantage, whereas not adopting them may hurt the performance of their companies. Decision makers make take guidance from these results to formulate strategies to adopt sustainable manufacturing practices. The sustainable manufacturing practices indices can be helpful in identifying the fitness of the leather industry for implementing sustainable manufacturing practices in circular economy contexts prior to implementation, as well as for modifying the current manufacturing practices.

\section{Conclusions and future directions of study}

The leather industry is ranked second in terms of contribution to the economic growth of Bangladesh. Therefore, it is necessary for the leather industry to adopt sustainable manufacturing practices to achieve a greater global competitive advantage. Sustainable manufacturing practices have been widely adopted by various manufacturing industries in developed countries. In Bangladesh, sustainable manufacturing practices are becoming increasingly popular due to pressure from buyers and the global market. Sustainable manufacturing practices in leather industries would undoubtedly be beneficial to the economic development of Bangladesh.

This study shows the positive impacts of various drivers for implementing sustainable manufacturing practices. This is the first crucial step for introducing sustainable manufacturing practices and the circular economy. In this study, we have used the systematic GTMA approach to determine the relative impact of the identified drivers. In this research, we have considered four drivers such as knowledge about the circular economy, customer awareness, leadership and commitment from top management, and governmental support and legislation for the sake of simplicity of analysis. Knowledge about the circular economy was shown to be the first priority driver due to its high positive impact on implementing sustainable manufacturing practices in the leather industry of Bangladesh. In future, other drivers could be considered for more in-depth analysis of the leather industry in Bangladesh.

We have derived the factors using the extant literature review and experts' opinion. Additional methods such the Analytic Hierarchy Process (AHP) or the fuzzy Analytic Hierarchy Process (FAHP) could be used to rank the factors in future relevant studies and then use the top ranked factors in a GTMA approach.

We believe the methodology undertaken in this research could be applied to other industries, including pharmaceuticals, textiles, chemicals and the plastics industry to examine drivers to sustainable manufacturing practices and the circular economy. 


\section{Appendix 1}

Table A1: Major drivers and sub-drivers with relevant references

\begin{tabular}{|c|c|c|c|}
\hline Major drivers & Sub-drivers & Simplified Meanings & $\begin{array}{l}\text { Relevant } \\
\text { Literature }\end{array}$ \\
\hline \multirow{5}{*}{$\begin{array}{l}\text { A. Knowledge } \\
\text { about } \\
\text { Circular } \\
\text { Economy } \\
(\mathrm{KCE})\end{array}$} & $\begin{array}{llr}1 & \text { Training and } \\
& \text { Education }(\mathrm{KCE} 1)\end{array}$ & $\begin{array}{l}\text { Practicing and having profound knowledge on } \\
\text { circular economy gives importance to proper } \\
\text { training at home \& abroad }\end{array}$ & \multirow{5}{*}{$\begin{array}{l}\text { (Bechtel et al., } \\
\text { 2013; Ghazilla } \\
\text { et al., 2015; } \\
\text { Lieder and } \\
\text { Rashid, 2016; } \\
\text { Macarthur, } \\
\text { 2014; Wu et } \\
\text { al., 2010) }\end{array}$} \\
\hline & $\begin{array}{ll}2 & \text { Availability of } \\
& \text { information (KCE2) }\end{array}$ & $\begin{array}{l}\text { Proper practice of circular economy demands } \\
\text { availability of related information }\end{array}$ & \\
\hline & $\begin{array}{ll}3 & \text { Employee } \\
& \text { involvement/motivat } \\
& \text { ion }(\mathrm{KCE} 3)\end{array}$ & $\begin{array}{l}\text { Practicing of SM and circular economy gives } \\
\text { some explicit tremor among the employees } \\
\text { which sustains their motivation }\end{array}$ & \\
\hline & $\begin{array}{l}\text { Knowledge } r \text { sharing } \\
\text { in supply chain } \\
(\mathrm{KCE} 4)\end{array}$ & $\begin{array}{l}\text { To sustain in the market, stakeholders of } \\
\text { different supply chain need to share their } \\
\text { knowledge and ideas which will help } \\
\text { manufacturers initiate new launches }\end{array}$ & \\
\hline & $\begin{array}{l}5 \text { Concerns about } \\
\text { environmental } \\
\text { impacts and the state } \\
\text { of the environment } \\
\text { (KCE5) }\end{array}$ & $\begin{array}{l}\text { Degradation of natural resources, energy and } \\
\text { interests on the importance of environmental } \\
\text { issues motivate to adopt circular economy }\end{array}$ & \\
\hline \multirow[t]{4}{*}{$\begin{array}{l}\text { B. } \text { Customer } \\
\text { Awareness } \\
\text { (CA) }\end{array}$} & 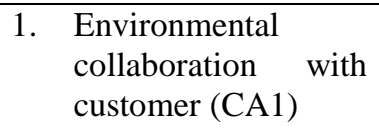 & $\begin{array}{l}\text { Issues of environmental collaboration with } \\
\text { customers help to create awareness about } \\
\text { circular economy }\end{array}$ & \multirow{4}{*}{$\begin{array}{l}\text { (Bechtel et al., } \\
\text { 2013; Bhool } \\
\text { and Narwal, } \\
\text { 2013; Hanna et } \\
\text { al., 2000; } \\
\text { Mudgal et al., } \\
\text { 2009; Walker } \\
\text { et al., 2008) }\end{array}$} \\
\hline & $\begin{array}{llr}\text { 2. } & \text { Global } & \text { climate } \\
\text { pressure } & \text { and } \\
\text { ecological } & \text { scarcity } \\
& \text { of resources } & \text { (CA2) }\end{array}$ & $\begin{array}{l}\text { Environmental pollution, degradation of } \\
\text { natural resources are prime concerns of the } \\
\text { present world and thus world forums demand } \\
\text { the adoption of circular economy to reduce } \\
\text { ecological scarcity of resources }\end{array}$ & \\
\hline & $\begin{array}{l}\text { 3. Community pressure } \\
\text { (CA3) }\end{array}$ & $\begin{array}{l}\text { Community pressure to reduce degradation of } \\
\text { environment initiates customer awareness on } \\
\text { environmental issues }\end{array}$ & \\
\hline & $\begin{array}{l}\text { 4. Customer awareness } \\
\text { to green initiatives } \\
\text { (CA4) }\end{array}$ & $\begin{array}{l}\text { Customers awareness on environmental } \\
\text { sustainability pressures manufacturers to } \\
\text { adopt sustainable manufacturing practices }\end{array}$ & \\
\hline \multirow{4}{*}{$\begin{array}{l}\text { C. Leadership } \\
\text { and } \\
\text { Commitme } \\
\text { nt From } \\
\text { Top } \\
\text { Manageme } \\
\text { nt (LCTP) }\end{array}$} & $\begin{array}{l}\text { 1. Collaboration } \\
\text { between } \\
\text { organizations } \\
\text { (LCTP1) }\end{array}$ & $\begin{array}{l}\text { Leadership comes first in the time of } \\
\text { collaborating between organizations to come } \\
\text { forward in stepping towards sustainable } \\
\text { manufacturing practices }\end{array}$ & \multirow{4}{*}{$\begin{array}{l}\text { (Bechtel et al., } \\
\text { 2013; Ghazilla } \\
\text { et al., 2015; } \\
\text { Green et al., } \\
\text { 1996; Mudgal } \\
\text { et al., 2009; } \\
\text { Mutingi, 2013; } \\
\text { Nordin et al., } \\
2014 \text {; van } \\
\text { Raaij et al., } \\
2008 \text { ) }\end{array}$} \\
\hline & $\begin{array}{l}\text { 2. } \text { Competitive } \\
\text { advantage (LCTP2) }\end{array}$ & $\begin{array}{l}\text { Sustainable manufacturing practices ensure } \\
\text { competitive advantages for the manufacturers } \\
\text { in the market }\end{array}$ & \\
\hline & $\begin{array}{l}\text { 3. } \text { Competitors } \\
\text { pressure towards } \\
\text { greening (LCTP3) }\end{array}$ & $\begin{array}{l}\text { To sustain in the competitive market, } \\
\text { manufacturers need to introduce sustainable } \\
\text { manufacturing practices, i.e. circular economy }\end{array}$ & \\
\hline & $\begin{array}{l}\text { 4. Introducing Cleaner } \\
\text { Technology } \\
\text { (LCTP4) }\end{array}$ & $\begin{array}{l}\text { Due the enormous significance of green } \\
\text { activities, cleaner technologies in the present } \\
\text { time, manufacturers are forced to adopt new } \\
\text { sustainable practices for sustainable } \\
\text { environment }\end{array}$ & \\
\hline
\end{tabular}




\begin{tabular}{|c|c|c|c|}
\hline & $\begin{array}{ll}\text { 5. } & \begin{array}{l}\text { Economic } \\
\text { (LCTP5) }\end{array}\end{array}$ & $\begin{array}{l}\text { The economic demand and crisis pressures to } \\
\text { adopt sustainable practices which impact on } \\
\text { optimal resources and energy thus ensures } \\
\text { economic benefits }\end{array}$ & \\
\hline \multirow{4}{*}{$\begin{array}{l}\text { D. Governmen } \\
\text { tal Support } \\
\text { and } \\
\text { Legislation } \\
\text { (GSL) }\end{array}$} & $\begin{array}{ll}\text { 1. } & \text { Funding from } \\
\text { Government (GSL1) }\end{array}$ & $\begin{array}{l}\text { To ensure proper sustainable manufacturing } \\
\text { practices government is pressured to fund for } \\
\text { smooth implementation }\end{array}$ & \multirow{4}{*}{$\begin{array}{l}\text { (Bechtel et al., } \\
\text { 2013; Diabat } \\
\text { and Govindan, } \\
2011 \text {; Nordin } \\
\text { et al., 2014; } \\
\text { Tay et al., } \\
2015 \text { ) }\end{array}$} \\
\hline & $\begin{array}{llr}\text { 2. } & \text { Reusing } & \text { and } \\
\text { recycling } & \text { materials } \\
\text { and } & \text { packaging } \\
\text { (GSL2) } & \end{array}$ & $\begin{array}{l}\text { Sustainable practices like reusing, recycling } \\
\text { are popular nowadays }\end{array}$ & \\
\hline & $\begin{array}{ll}\text { 3. } & \text { ISO } 14001 \\
& \text { certification }(\mathrm{GSL} 3)\end{array}$ & $\begin{array}{l}\text { To comply with international rules and } \\
\text { regulations, i.e. ISO 14001, manufacturers } \\
\text { are forced to adopt sustainable manufacturing } \\
\text { practices throughout the process }\end{array}$ & \\
\hline & $\begin{array}{l}\text { 4. Environmental } \\
\text { collaboration with } \\
\text { suppliers (GSL4) }\end{array}$ & $\begin{array}{l}\text { To comply with the total quality and } \\
\text { sustainable manufacturing practices, suppliers } \\
\text { are pressured to maintain environmental } \\
\text { collaboration for smooth operations }\end{array}$ & \\
\hline
\end{tabular}

\section{References}

Agamuthu, P., Khidzir, K.M., Hamid, F.S., 2009. Drivers of sustainable waste management in Asia. Waste Manag. Res. 27, 625-633. doi:10.1177/0734242X09103191

Alayón, C., Säfsten, K., Johansson, G., 2017. Conceptual sustainable production principles in practice: Do they reflect what companies do? J. Clean. Prod. 141, 693-701. doi:10.1016/j.jclepro.2016.09.079

Álvarez, M.E.P., Bárcena, M.M., González, F.A., 2017. On the sustainability of machining processes. Proposal for a unified framework through the triple bottom-line from an understanding review. J. Clean. Prod. 142, 3890-3904. doi:10.1016/j.jclepro.2016.10.071

Andersen, M.S., 2007. An introductory note on the environmental economics of the circular economy. Sustain. Sci. 2, 133-140. doi:10.1007/s11625-006-0013-6

Andrews, D., 2015. The circular economy, design thinking and education for sustainability. Local Econ. 30, 305-315. doi:10.1177/0269094215578226

Baldwin, J.S., Allen, P.M., Winder, B., Ridgway, K., 2005. Modelling manufacturing evolution: Thoughts on sustainable industrial development. J. Clean. Prod. 13, 887-902. doi:10.1016/j.jclepro.2004.04.009

Bechtel, N., Bojko, R., Völkel, R., 2013. Be in the Loop: Circular Economy \& Strategic Sustainable Development. Master Thesis. Blekinge Institute of Technology, Sweden.

Bellantuono, N., Carbonara, N., Pontrandolfo, P., 2017. The organization of eco-industrial parks and their sustainable practices. J. Clean. Prod. 161, 362-375. doi:10.1016/j.jclepro.2017.05.082

Bhanot, N., Rao, P.V., Deshmukh, S.G., 2017. An integrated approach for analysing the enablers and barriers of sustainable manufacturing. J. Clean. Prod. 142, 4412-4439. 
doi:10.1016/j.jclepro.2016.11.123

Bhool, R., Narwal, M.S., 2013. An Analysis of Drivers Affecting the Implementation of Green Supply Chain Management for the Indian Manufacturing Industries. Int. J. Res. Eng. Technol. 2, 242-254.

Bhowmik, A.K., 2013. Industries' Location as Jeopardy for Sustainable Urban Development in Asia: A Review of the Bangladesh Leather Processing Industry Relocation Plan. Environ. Urban. ASIA 4, 93-119. doi:10.1177/0975425313477749

Bollobás, B., 1999. Modern graph theory. Comput. Math. with Appl. 37, 136. doi:10.1016/S0898-1221(99)90429-7

Cordoba, D.B., Veshagh, A., 2013. Managing Eco Design and Sustainable Manufacturing, in: Re-Engineering Manufacturing for Sustainability. Springer, Singapore, Singapore, pp. 59-67. doi:10.1007/978-981-4451-48-2_10

Diabat, A., Govindan, K., 2011. An analysis of the drivers affecting the implementation of green supply chain management. Resour. Conserv. Recycl. 55, 659-667. doi:10.1016/j.resconrec.2010.12.002

Elmualim, A., Valle, R., Kwawu, W., 2012. Discerning policy and drivers for sustainable facilities management practice. Int. J. Sustain. Built Environ. 1, 16-25. doi:10.1016/j.ijsbe.2012.03.001

Esmaeilian, B., Behdad, S., Wang, B., 2016. The evolution and future of manufacturing: A review. J. Manuf. Syst. 39, 79-100. doi:10.1016/j.jmsy.2016.03.001

Fathi, M.R., Safari, H., Faghih, A., 2013. Integration of Graph Theory and Matrix Approach with Fuzzy AHP for Equipment Selection. J. Ind. Eng. Manag. 6, 477-494. doi:10.3926/jiem.403

Feng, S.C., Joung, C.B., 2011. A measurement infrastructure for sustainable manufacturing. Int. J. Sustain. Manuf. 2, 204-221. doi:10.1504/IJSM.2011.042152

Fischer, A., Pascucci, S., 2017. Institutional incentives in circular economy transition: The case of material use in the Dutch textile industry. J. Clean. Prod. 155, 17-32. doi:10.1016/j.jclepro.2016.12.038

Geldermann, J., Treitz, M., Rentz, O., 2007. Towards sustainable production networks. Int. J. Prod. Res. 45, 4207-4224. doi:10.1080/00207540701440014

Genovese, A., Acquaye, A.A., Figueroa, A., Koh, S.., 2017. Sustainable supply chain management and the transition towards a circular economy: Evidence and some applications. Omega 66, 344-357. doi:10.1016/j.omega.2015.05.015

Ghazilla, R.A.R., Sakundarini, N., Abdul-Rashid, S.H., Ayub, N.S., Olugu, E.U., Musa, S.N., 2015. Drivers and barriers analysis for green manufacturing practices in Malaysian smes: A preliminary findings. Procedia CIRP 26, 658-663. doi:10.1016/j.procir.2015.02.085

Govindan, K., Diabat, A., Madan Shankar, K., 2015. Analyzing the drivers of green manufacturing with fuzzy approach. J. Clean. Prod. 96, 182-193. doi:10.1016/j.jclepro.2014.02.054 
Green, K., Morton, B., New, S., 1996. Purchasing and environmental management: interactions, policies and opportunities. Bus. Strateg. Environ. 5, 188-197. doi:10.1002/(SICI)1099-0836(199609)5:3<188::AID-BSE60>3.0.CO;2-P

Grover, S., Agrawal, V.P., Khan, I. a., 2004. A digraph approach to TQM evaluation of an industry. Int. J. Prod. Res. 42, 4031-4053. doi:10.1080/00207540410001704032

Guo, J., Mao, H., Wang, T., 2010. Ecological Industry: A Sustainable Economy Developing Pattern. J. Sustain. Dev. 3, 239-242. doi:10.5539/jsd.v3n3p239

Gupta, K., Laubscher, R.F., Davim, J.P., Jain, N.K., 2016. Recent developments in sustainable manufacturing of gears: A review. J. Clean. Prod. 112, 3320-3330. doi:10.1016/j.jclepro.2015.09.133

Hanna, M.D., Newman, W.R., Johnson, P., 2000. Linking operational and environmental improvement through employee involvement. Int. J. Oper. Prod. Manag. 20, 148-165. doi:10.1108/01443570010304233

Hoque, A., Clarke, A., 2013. Greening of industries in Bangladesh: Pollution prevention practices. J. Clean. Prod. 51, 47-56. doi:10.1016/j.jclepro.2012.09.008

Hu, J., Xiao, Z., Zhou, R., Deng, W., Wang, M., Ma, S., 2011. Ecological utilization of leather tannery waste with circular economy model. J. Clean. Prod. 19, 221-228. doi:10.1016/j.jclepro.2010.09.018

Ijomah, W.L., 2010. The application of remanufacturing in sustainable manufacture. Proc. Inst. Civ. Eng. - Waste Resour. Manag. 163, 157-163. doi:10.1680/warm.2010.163.4.157

Jawahir, I.S., Bradley, R., 2016. Technological Elements of Circular Economy and the Principles of 6R-Based Closed-loop Material Flow in Sustainable Manufacturing. Procedia CIRP 40, 103-108. doi:10.1016/j.procir.2016.01.067

Jayal, A.D., Badurdeen, F., Dillon, O.W., Jawahir, I.S., 2010. Sustainable manufacturing: Modeling and optimization challenges at the product, process and system levels. CIRP J. Manuf. Sci. Technol. 2, 144-152. doi:10.1016/j.cirpj.2010.03.006

Jurkat, W.B., Ryser, H.J., 1966. Matrix factorization of determinants and permanents. J. Algebr. 3, 1-27. doi:10.1016/0021-8693(66)90016-0

Kaur, A., Kanda, A., Deshmukh, S.G., 2006. A graph theoretic approach for supply chain coordination. Int. J. Logist. Syst. Manag. 2, 321-341. doi:10.1504/IJLSM.2006.010379

Keeble, B.., 1988. The Brundtland report: "Our common future.” Med. War 4, 17-25. doi:10.1080/07488008808408783

Kulatunga, A.K., Jayatilaka, P.R., Jayawickrama, M., 2013. Drivers and barriers to implement sustainable manufacturing concepts in Sri Lankan manufacturing sector, in: 11th Global Conference on Sustainable Manufacturing. Universitätsverlag der TU Berlin, Berlin, Germany, pp. 171-176. doi:10.13140/2.1.2952.1927

Kulkarni, S., 2005. Graph theory and matrix approach for performance evaluation of TQM in Indian industries. TQM Mag. 17, 509-526. doi:10.1108/09544780510627615 
Lewandowski, M., 2016. Designing the business models for circular economy-towards the conceptual framework. Sustainability 8, 1-28. doi:10.3390/su8010043

Lieder, M., Rashid, A., 2016. Towards circular economy implementation: A comprehensive review in context of manufacturing industry. J. Clean. Prod. 115, 36-51. doi:10.1016/j.jclepro.2015.12.042

Lorek, S., Spangenberg, J.H., 2014. Sustainable consumption within a sustainable economy Beyond green growth and green economies. J. Clean. Prod. 63, 33-44. doi:10.1016/j.jclepro.2013.08.045

Macarthur, E., 2014. Towards the Circular Economy: Accelerating the scale-up across global supply chains, World Economic Forum. Geneva. doi:10.1162/108819806775545321

Macarthur, E., 2013. Towards the Circular Economy: Opportunities for the consumer goods sector, Ellen MacArthur Foundation. Cowes, United Kingdom.

Mann, H., Kumar, U., Kumar, V., Mann, I.J.S., 2010. Drivers of Sustainable Supply Chain Management. IUP J. Oper. Manag. 9, 52-64.

Mittal, V.K., Sangwan, K.S., 2014. Prioritizing drivers for green manufacturing: Environmental, social and economic perspectives. Procedia CIRP 15, 135-140. doi:10.1016/j.procir.2014.06.038

Moktadir, M.A., Ahmed, S., Tuj Zohra, F., Sultana, R., 2017. Productivity Improvement by Work Study Technique: A Case on Leather Products Industry of Bangladesh. Ind. Eng. Manag. 6, 1-11. doi:10.4172/2169-0316.1000207

Moreno, M., Braithwaite, N., Cooper, T., 2014. Moving beyond the circular economy, in: Proceedings of Going Green-CARE INNOVATION. European Urban Knowledge Netwrok, Vienna, Austria, pp. 1-10.

Mudgal, R.K., Shankar, R., Talib, P., Raj, T., 2009. Greening the supply chain practices: an Indian perspective of enablers' relationships. Int. J. Adv. Oper. Manag. 1, 151. doi:10.1504/IJAOM.2009.030671

Muduli, K., Govindan, K., Barve, A., Geng, Y., 2013. Barriers to green supply chain management in Indian mining industries: A graph theoretic approach. J. Clean. Prod. 47, 335-344. doi:10.1016/j.jclepro.2012.10.030

Mutingi, M., 2013. Developing green supply chain management strategies: A taxonomic approach. J. Ind. Eng. Manag. 6, 525-546. doi:10.3926/jiem.475

Nordin, N., Ashari, H., Hassan, M.G., 2014. Drivers and barriers in sustainable manufacturing implementation in Malaysian manufacturing firms, in: IEEE International Conference on Industrial Engineering and Engineering Management. IEEE, Sunway, Malaysia, pp. 687-691. doi:10.1109/IEEM.2014.7058726

Nowosielski, R., Babilas, R., Pilarczyk, W., 2007. Sustainable technology as a basis of cleaner production. J. Achiev. Mater. Manuf. Eng. 20, 527-530.

Paul, H.L., Antunes, A.P.M., Covington, A.D., Evans, P., Phillips, P.S., 2013. Bangladeshi Leather Industry: An Overview of Recent Sustainable Developments. J. Soc. Leather Technol. Chem. 97, 25-32. doi:10.1016/S0011-9164(04)00193-6 
Pishvaee, M.S., Rabbani, M., 2011. A graph theoretic-based heuristic algorithm for responsive supply chain network design with direct and indirect shipment. Adv. Eng. Softw. 42, 57-63. doi:10.1016/j.advengsoft.2010.11.001

Pomponi, F., Moncaster, A., 2017. Circular economy for the built environment: A research framework. J. Clean. Prod. 143, 710-718. doi:10.1016/j.jclepro.2016.12.055

Preston, F., 2012. A Global Redesign? Shaping the Circular Economy, Energy, Environment and Resource Governance. London.

Pringle, T., Barwood, M., Rahimifard, S., 2016. The Challenges in Achieving a Circular Economy within Leather Recycling. Procedia CIRP 48, 544-549. doi:10.1016/j.procir.2016.04.112

Programme des Nations Unies pour l'environnement, 2011. Towards a Green Economy: Pathways to Sustainable Development and Poverty Eradication, Sustainable Development. United Nations Environment Programme.

Rao, R.V., 2006. A material selection model using graph theory and matrix approach. Mater. Sci. Eng. A 431, 248-255. doi:10.1016/j.msea.2006.06.006

Rezaei, J., 2015. Best-worst multi-criteria decision-making method. Omega 53, 49-57. doi:10.1016/j.omega.2014.11.009

Roberts, S.J.F., Ball, P.D., 2014. Developing a library of sustainable manufacturing practices. Procedia CIRP 15, 159-164. doi:10.1016/j.procir.2014.06.054

Rosen, M.A., Kishawy, H.A., 2012. Sustainable manufacturing and design: Concepts, practices and needs. Sustainability 4, 154-174. doi:10.3390/su4020154

Saaty, T.L., 2004. Decision making - the Analytic Hierarchy and Network Processes (AHP/ANP). J. Syst. Sci. Syst. Eng. 13, 1-35. doi:10.1007/s11518-006-0151-5

Sáez-Martínez, F.J., Lefebvre, G., Hernández, J.J., Clark, J.H., 2016. Drivers of sustainable cleaner production and sustainable energy options. J. Clean. Prod. 138, 1-7. doi:10.1016/j.jclepro.2016.08.094

Schrader, U., Thøgersen, J., 2011. Putting Sustainable Consumption into Practice. J. Consum. Policy 34, 3-8. doi:10.1007/s10603-011-9154-9

Seymour, P., Schrijver, A., Diestel, R., 2005. Graph Theory, Oberwolfach Reports. doi:10.4171/OWR/2005/03

Shankar, K.M., Kannan, D., Kumar, P.U., 2017. Analyzing sustainable manufacturing practices - A case study in Indian context. J. Clean. Prod. 164, 1332-1343. doi:10.1016/j.jclepro.2017.05.097

Sheldon, R.A., 2014. Green and sustainable manufacture of chemicals from biomass: state of the art. Green Chem. 16, 950-963. doi:10.1039/C3GC41935E

Siemieniuch, C.E., Sinclair, M.A., Henshaw, M.J.C., 2015. Global drivers, sustainable manufacturing and systems ergonomics. Appl. Ergon. 51, 104-119.

doi:10.1016/j.apergo.2015.04.018 
Smith, L., Ball, P., 2012. Steps towards sustainable manufacturing through modelling material, energy and waste flows. Int. J. Prod. Econ. 140, 227-238. doi:10.1016/j.ijpe.2012.01.036

Stahel, W.R., 2016. The circular economy. Nature 531, 435-438. doi:10.1038/531435a

Stock, T., Seliger, G., 2016. Opportunities of Sustainable Manufacturing in Industry 4.0. Procedia CIRP 40, 536-541. doi:10.1016/j.procir.2016.01.129

Su, B., Heshmati, A., Geng, Y., Yu, X., 2013. A review of the circular economy in China: Moving from rhetoric to implementation. J. Clean. Prod. 42, 215-227. doi:10.1016/j.jclepro.2012.11.020

Syed, S.B., Dadwal, V., Rutter, P., Storr, J., Hightower, J.D., Gooden, R., Carlet, J., Bagheri Nejad, S., Kelley, E.T., Donaldson, L., Pittet, D., 2012. Developed-developing country partnerships: benefits to developed countries? Global. Health 8, 1-10. doi:10.1186/1744-8603-8-17

Tan, Y., Shen, L., Yao, H., 2011. Sustainable construction practice and contractors' competitiveness: A preliminary study. Habitat Int. 35, 225-230. doi:10.1016/j.habitatint.2010.09.008

Tay, M.Y., Rahman, A.A., Aziz, Y.A., Sidek, S., 2015. A Review on Drivers and Barriers towards Sustainable Supply Chain Practices. Int. J. Soc. Sci. Humanit. 5, 892-897. doi:10.7763/IJSSH.2015.V5.575

van Raaij, E., Brandon-Jones, A., Lamming, R., Walker, H., Di Sisto, L., McBain, D., 2008. Drivers and barriers to environmental supply chain management practices: Lessons from the public and private sectors. J. Purch. Supply Manag. 14, 69-85. doi:10.1016/j.pursup.2008.01.007

Vogel, J.H., Nguyen, H., Giovannini, R., Ignowski, J., Garger, S., Salgotra, A., Tom, J., 2012. A new large-scale manufacturing platform for complex biopharmaceuticals. Biotechnol. Bioeng. 109, 3049-3058. doi:10.1002/bit.24578

Wagner, S.M., Neshat, N., 2010. Assessing the vulnerability of supply chains using graph theory. Int. J. Prod. Econ. 126, 121-129. doi:10.1016/j.ijpe.2009.10.007

Walker, H., Di Sisto, L., McBain, D., 2008. Drivers and barriers to environmental supply chain management practices: Lessons from the public and private sectors. J. Purch. Supply Manag. 14, 69-85. doi:10.1016/j.pursup.2008.01.007

Wang, L., Bi, Z.M., 2013. Challenges for better sustainable manufacturing, in: Advances in Sustainable and Competitive Manufacturing Systems, Lecture Notes in Mechanical Engineering. Springer, Heidelberg, Switzerland, pp. 1209-1221. doi:10.1007/978-3319-00557-7_99

Wang, Z., Subramanian, N., Gunasekaran, A., Abdulrahman, M.D., Liu, C., 2015. Composite sustainable manufacturing practice and performance framework: Chinese auto-parts suppliers' perspective. Int. J. Prod. Econ. 170, 219-233. doi:10.1016/j.ijpe.2015.09.035

Westkämper, E., 2008. Manufuture and sustainable manufacturing, in: Manufacturing Systems and Technologies for the New Frontier. Springer, Tokyo, Japan, pp. 11-14. doi:10.1007/978-1-84800-267-8_3 
Wu, G., Cheng, Y., Huang, S., 2010. The study of knowledge transfer and green management performance in green supply chain management. African J. Bus. Manag. 4, 44-48.

Ying, J., Li-jun, Z., 2012. Study on Green Supply Chain Management Based on Circular Economy. Phys. Procedia 25, 1682-1688. doi:10.1016/j.phpro.2012.03.295

Yuan, Z., Bi, J., Moriguichi, Y., 2006. The Circular Economy: A New Development Strategy in China. J. Ind. Ecol. 10, 4-8. doi:10.1162/108819806775545321

Zeqiang, Z., Wenming, C., 2006. Reverse logistics and the forming of circular economy hypercycle structure, in: International Conference on Management of Logistics, Environment. SEI online, Hong Kong, pp. 612-617.

Zils, M., 2014. Moving toward a circular economy, McKinsey Quarterly. Munich. Accessed from www.mckinsey.com/business-functions/sustainability-and-resourceproductivity/our-insights/moving-toward-a-circular-economy on 23 March 2017. 